\title{
Dialectics of Economic and Legal Transformations in Russia
}

Submitted 06/06/20, 1st revision 07/07/20, 2nd revision 14/08/20, accepted 15/09/20

Vasily I. Vlasov ${ }^{1}$, Svetlana V. Denisenko ${ }^{2}$, Natalya A. Pakhomova ${ }^{3}$, Yulia A. Shulgach $^{4}$, Veronika V. Kolesnik ${ }^{5}$, Alina V. Poltavtseva ${ }^{6}$

Abstract:

Purpose: The article is devoted to the problem of the relationship and interdependence of economic and legal transformations. Based on an analysis of the last 160 years of Russia's development, the authors have tried to show the failure of providing unilateral reforms, either economic or political.

Design/Methodology/Approach: The mutual influence of economic and political processes has been revealed. Particular attention is paid to the problem of state security in the context of reform processes. The research is based on the method of systems analysis, as well as dialectical, theoretical, legal, and historical methods.

Findings: The dead-end nature of totalitarian development is also shown as well as the problem shifting from it. The authors concluded that in the conditions of an underdeveloped civil society in Russia, economic and legal reforms should be simultaneous and sequential, while the state authorities are responsible for ensuring internal security.

Practical Implications: It is necessary to prevent interference in the transformative processes of both radical and ultra-radical (left) elements. Both in the past and in the present a lot

${ }^{I}$ Doctor of Philosophy, Professor of the Department of International Law of the Rostov branch of the Russian State University of Justice, Rostov-on-Don, Russian Federation, vlasovvi@mail.ru

${ }^{2}$ PhD (Law), Associate Professor, Head of the Department of International Law of the Rostov branch of the Russian State University of Justice, Rostov-on-Don, Russian Federation, s.v.denisenko@bk.ru

${ }^{3} \mathrm{PhD}$ (History), Associate Professor of the Department of International Law of the Rostov branch of the Russian State University of Justice, Rostov-on-Don, Russian Federation, pakhomovanat761@yandex.ru

${ }^{3} \mathrm{PhD}$ (History), Associate Professor of the Department of International Law of the Rostov branch of the Russian State University of Justice, Rostov-on-Don, Russian Federation, usya76@mail.ru

${ }^{4}$ PhD (Law), Associate Professor of the Department of International Law of the Rostov branch of the Russian State University of Justice, Rostov-on-Don, Russian Federation, nikkipohta@mail.ru

${ }^{5}$ PhD (Law), candidate of legal science, Associate Professor of the Department of Civil Law of the Rostov branch of the Russian State University of Justice, Rostov-on-Don, Russian Federation.

${ }^{6}$ Lecturer at the Department of Civil Procedure, Rostov State University of Economics, Rostov-on-Don, Russian Federation,.gr_process38@mail.ru 
depends on the personality of the leader in Russia and on the strength of the power structures, exactly the security service.

Originality/Value: The transition from totalitarian development to post-totalitarian development is accompanied by large-scale economic and political reforms. Moreover, two options are possible: the revolutionary, observed in Europe, and the reform of histories (China and Vietnam), the difference between which lies in the elimination or preservation of the dictatorship of the Communist Party.

Keywords: Reforms, state power, economics, law, regime.

JEL codes: 038 .

Paper type: Research article.

\section{Introduction}

The history of Russia over the past 160 years demonstrates a special dialectical connection between economic transformations and legal reforms. The former was always impossible without the latter. However, it was impossible to start legal reforms without relying on changes in economic life. Stagnation in economic development has always been accompanied by serious failures in legal policy. Although it should be noted that economic reforms, not supported by appropriate political and legal principles, also collapsed. In Russia it is largely due to the specifics of the development of political and state authorities.

The study of the dialectics of economic and legal transformations in Russia is of particular importance for understanding the processes of country's legal and social statehood's development. The hypothesis put forward in the article is that a successful progress through transformations provides for a harmonious combination of their economic and legal aspects, alongside with the proper activity of civil society and a strong, stable state power capable of resisting extremism and radicalism.

\section{Literature Review}

The problem of the relationship between economic and legal transformations in the context of European statehood is in the focus of attention of Russian scientists (Chirkin, 2000; Tikhomirov, 2013). However, still there is much to be discussed. Research of the economic and legal processes' interdependence is related to the level of development of Russian civil society and the activity of state structures, primarily executive bodies (Vlasov, 2010; Vlasova, 2009).

The historical material contained in the works of Russian and foreign scientists is of great importance for this research. It allows us to understand the direction of economic and legal processes development in Russia and to compare them with the processes in other countries (Syrykh, 2014; Ivashko, 2016). 
The study of the processes of economic and legal transformations mutual influence is quite relevant in modern conditions and is in the field of both economic and legal sciences, being the subject of this article.

\section{Methods of Conducting Research}

The research is based on the method of systems analysis, as well as dialectical, theoretical, legal, and historical methods. The method of systems analysis made it possible to construct a presentation of the material in a certain logical order based on the interconnectedness of the phenomena under study. The dialectical method ensures the objectivity of the research, allowing the analysis of the studied phenomenon in progress. The theoretical and legal method makes it possible to assess the legal aspects of the problem. And the historical method involves using historical research materials. Taken together, all the above methods contribute to creating a holistic picture of the problem under consideration

\section{Results}

\subsection{Successful Economic Development and Liberal-Democratic Reforms in Russian Empire}

The first truly major economic reform in Russia was the peasant reform of 1861, which abolished serfdom. Of course, let us not forget that it went hand in hand with the financial reform. It was these two major transformations that opened the era of the great reforms of Alexander II, highlighting the economic aspect of the policy of the Russian leadership. It provided, first, taking into account the material interests of landowners and peasants, and it was necessary to put urgently in order Russian finances. It was the purpose for which the State Bank was created in 1860.

The peasant reform was primarily economic, as evidenced by the problem of redemption payments and the size of the land allotment for the peasant. And only then social and political issues - that is the organization of peasant self-government, and the legal ones - such as the participation of peasants in the zemstvo (rural selfgovernment) elections and in the jury - appeared (Syrykh, 2014).

The abolition of serfdom, financial reform, the introduction of zemstvo and municipal self-government, the creation of a virtually new judicial system, educational reform (both secular and spiritual) and military reform sharply intensified the development of civil relations, contributing to the country's transition from a corporate class society to a civil one, which in turn demanded a resolution of the parliamentary representation issue. Alexander's "revolution from above" demanded its completion. Large-scale economic and legal transformations were to be crowned with a gradual transition to a dualistic monarchy, that is, with the solution of the main issue of any revolution - the issue of power. 
Due to several circumstances, the great reformer, the Tsar-Liberator could not and did not have time to begin solving this issue. (He was just killed.) His successor, his son, Alexander III, was completely unprepared to continue this activity. And although in economic terms, the forward movement continued, but Russia's legal development was spinning in place. The new emperor and his government were not able to assess the current situation adequately, as evidenced by the reforms of Alexander III in the sphere of justice, zemstvo and municipal self-government, education, which received the name of counter-reforms.

The leadership of the empire did not want to pay attention to the fact that all developed states had become constitutional. The monarchies of Great Britain and Scandinavia became parliamentary. In France and Italy, there was a drift towards a parliamentary republic and monarchy. Dualistic monarchies were established in Germany and Austria-Hungary. In 1889, the Japanese Empire became dualistic after adopting a constitution that year. Only China, Persia and Turkey remained despotic monarchies, being the most economically and politically backward states. The question arose who was the Russian Empire equal to?

Immediately after Alexander III came to power, all liberals were expelled from the government. The Minister of Internal Affairs M. T. Loris-Melikhov, the Minister of Finance A. A. Abaza, and the Minister of War D. A. Milyutin resigned. The closest associate of Alexander II, his brother, Grand Duke Konstantin Nikolaevich, was removed from the leadership of the naval ministry. And in the future, Alexander III and his son Nicholas II will consider liberals as their main enemies.

By the mid-eighties, the Alexander III's political course concept was finally formed. It would later be adopted by Nicholas II. Its main focus was on the importance of faithfully maintaining the sanctity of autocracy, the inadmissibility of any political state administration democratic transformations, on power centralization and limiting the rights of local self-government, on the "complete inviolability" of the nobility rights. Later this concept was called "neo-absolutism" and, as the further history of Russia showed, it was erroneous. But the Empire was on the rise and the state leaders did not want to reckon with anything. The population grew, as they would say now, at a fantastic rate.

In 1861 the population was 73 million people, in 1881 - 100 million people, in 1897 125 million people, in 1910 - 163 million people. In other words, in the conditions of post-reform development, the population of the empire doubled in 50 years. This means that the economic and social situation in the country was not so bad. (Ivashko, 2016). The activity of finance ministers N.N. Bunge, I.A. Vyshegradskiy and S. Yu. Witte, who replaced each other, was quite successful, the latter showed himself both as a minister of foreign affairs and as a prime minister. Their financial, economic, and legal activities laid the foundations for a political course that could prevent Russia from revolution. 
N.H. Bunge strove to expand the domestic market while simultaneously developing agriculture and industry, with the aim of strengthening the position of the middle classes. He advocated the development of tax legislation favorable to the development of industry and agriculture, being opposed to state financing of industry.

At the turn of the eighties-nineties I. A. Vyshegradskiy continued the course set by his predecessor with the main emphasis on the financial resources accumulation and strengthening of the ruble. He strengthened the protectionist policy and ensured an increase in the import of foreign capital into Russia. As a result, it was possible to eliminate the state budget deficit. The economic policy of the finance ministers contributed to the accelerated development of industrial production, and as a result, the industrial revolution ended in Russia.

In 1892, the talented financier and statesman S. Yu. Witte became the head of the financial department. It was he who promised Alexander III to bring Russia into top of the leading industrialized countries in 20 years without carrying out political reforms. After the death of Alexander Alexandrovich, Witte introduced a gold standard in Russia, which made it possible to attract foreign capital to Russia and strengthen the country's monetary system. And at the beginning of the 20th century, Russia, being an agro-industrial country, became the world's fourth in terms of the total volume of industrial production.

All the above indicates that the economic course of the country was quite correct. And the question arises: why, at the beginning of the 20th century, a real revolutionary situation is developing in Russia. Within 10 years two revolutions of 1905-07 and 1917-22 took place. Moreover, if one there were just isolated armed clashes during the first revolution, the second one was accompanied by a large-scale civil war, in which more than ten million people lost their lives, and more than two million people found themselves in emigration. How did it happened that a strong power descended into revolutionary chaos (interesting is the fact that there was no revolutionary situation in Russia before the second revolution).

There were many reasons for such a development, but first, attention should be paid to the Russian autocracy. The absolute monarchy provided sufficient conditions for effective domestic and foreign policy. It ensured the ability to make individual decisions quickly, the constancy of the staff with the possibility of replacing any of the representatives of the higher bureaucracy, stimulating the activity of executive bodies working for the monarch, subordinating all forces and means to solving the task (Vlasov, 2010).

However, the personality of the country's leader became of great importance. Both Alexander II and Alexander III were strong personalities, which could not be said about Nicholas II. He inherited a powerful state, successfully developing economically and in need of liberal political reforms. As B.N. Chicherin (our Montesquieu) believed, there was a need for popular representation at the imperial 
level. Russian civil society was ready for this. But Nicholas II was a prominent representative of the Romanov family degeneration processes.

The spread of the subversive political ideology of utopian socialism in Russia also should be mentioned. It was presented in two versions at once - social democratic (Marxist) and Esser. In March 1898, the first congress of the RSDLP took place in Minsk, and in 1900, in Kharkov the creation of the Socialist Revolutionary Party (Esser) was proclaimed. Much has been written in Soviet historical literature about the "tsarist secret police". Russia was characterized as a police state. In fact, the development of the police, gendarmerie, counterintelligence was, to put it mildly, insufficient. Firstly, there was virtually no counterintelligence, and the police and gendarmerie were few. Secondly, the weak point of the political investigation in Russia was analytical activity. The leadership of the empire discouraged talented scientists, legal analysts, and sociologists (such as M.M. Kovalevsky, B.N. Chicherin, G.F. Shershenevich). B.N. Chicherin was one of the first to point out the growing danger of the utopian socialism ideology for Russia. But until 1917 the leaders of the empire considered the Constitutional Democrats (or Cadets) and the Octobrists as their main opponents (Avrutin, 2003).

The adventurous foreign policy of Nicholas II's government, his reluctance to negotiate with civil society, literally provoked the First Russian Revolution. At that time, the Russian establishment had enough strength to overcome the revolutionary crisis through the implementation of liberal reforms, the suppression of limited armed uprisings and the beginning of the transition to a dualistic monarchy, which was expressed in the establishment of the June Third System.

The two first prime ministers, S. Yu. Witte, and P.A. Stolypin, consistently played an important role in calming the political situation. The latter began the first series of reforms in Russia that contributed to the further growth of the Russian economy and, above all, agriculture. The process of its socialization and intensification began, and since 1909 there was a steady growth in agricultural production marketability.

However, Stolypin's reforms had a pronounced Bonapartist character. It was not without reason that Stolypin was compared to Bismarck (it was the Bonapartist regime that was the only way to preserve the monarchy in Russia, but the Romanovs did not understand it). However, if Bismarck enjoyed the full support of the first German emperor, Stolypin faced fierce resistance from the court camarilla, whose views were generally shared by Nicholas II. He was neither a reformer, like his grandfather, nor a sovereign like his father. With his connivance, Stolypin was killed in 1911, and in 6 years Russia plunged into revolutionary chaos.

Thus, successful economic development, not supported by the corresponding liberaldemocratic reforms, on the one hand, and without a reliable protective policy (police and security services), on the other hand, is not able to protect the country from serious 
social upheavals that can lead to the destruction of the economy and to rampant extremism, a vivid example of which was the Second Russian Revolution of 1917 1922.

\subsection{Economic Policy, Legal Policy, and Internal Party Policy under the Conditions of Totalitarian Development}

Having won the white armies of Kolchak and Yudenich, Denikin and Wrangel in the civil war, at the beginning of 1921 the Bolsheviks found themselves on the brink of a catastrophe that grew out of their policy of war communism. The uprising of peasants and Cossacks engulfed Western Siberia, Tambov, Voronezh and Saratov provinces, the North Caucasus, the Altai Mountains (Gorny Altai), and Central Asia. Kronstadt, the stronghold of the Bolsheviks in the Baltic, rebelled. Their key slogan was: "Power to the Soviets, but not to the parties." Why?

Already in the summer of 1918, the party committees and revolutionary committees of the Bolsheviks became the core of the state administration system. The Communist Party, or rather its apparatus, monopolized the political and state power in the country. All major issues of state administration were resolved at the annual party congresses. The VIIIth and the Xth Congress were epoch-making. A single-party system, which is one of the main features of any totalitarian statehood, was entrenched in Soviet Russia. The Political Bureau (Politburo) of the Central Committee of the Communist Party started to play a primary role in state administration. Moreover, the vertical of state security was introduced in addition to the party vertical (Central Committee Regional Committee - Local Committee (Raikom)). In December 1917, the AllRussian Extraordinary Commission for Combating Counter-Revolution and Sabotage (VChK) was created, which had a broad network throughout the country. It concentrated enormous powers in its hands, combining in one department both the investigation, and the court, as well as the enforcement of sentences. As a result, having proclaimed the dictatorship of the proletariat, the Bolshevik Party, established its own dictatorship, thus building a party state of a totalitarian type. (Krasnov and Shablinsky, 2008)

However, the first years of the dictatorship were indicated with a certain degree of democracy within the Communist Party itself. Its Xth Congress, held in 1921, highlighted the factional structure of the party which had not become completely totalitarian by that moment. Under the discussion a New Economic Policy (NEP) was developed, which was enshrined in the resolution of the X-th Congress of the RCP (b) "On The Replacement Of The Surplus Appropriation System By The Tax In Kind" and a similar decree of the All-Russian Central Executive Committee in March 1921.

In 1923-1924 the peasants were allowed (at their request) to pay the tax-in-kind in food and money. In 1924-1925, the transition to the monetary taxation of the village was carried out. It was the NEP that undermined the social roots of the insurgency, 
and in 1921-1922 its main centers were eliminated. The Great Russian Revolution of 1917-1922 was over.

Market relations on the legal basis in the countryside entailed the restructuring of the entire economic mechanism. 1921-1924 faced management reforms in industry, trade, cooperation, as well as monetary and credit and financial reforms. By the end of 1922, industry was denationalized. $1 / 3$ of the previously nationalized enterprises remained state-owned. The main integrative indicator of the country's economic development during the NEP was the national income growth. By 1926, it exceeded the 1921 level by 2.3 times. For the workers, however, this meant that by 1926 their average wages were $93.7 \%$ of the level of tsarist Russia. The income of the peasantry increased much more significantly. If the average monthly income of a peasant was 71 rubles in 1913, then in 1926 it was 115.5 rubles.

At the same time economic gap between Russia and the advanced Western countries continued to grow. (Indeed, the deindustrialization of Russia took place for the years of the revolution). In 1926 F.E. Dzerzhinsky, the chairman of the All-Union Supreme Council of National Economy of the USSR and the chief of the political police OGPU (The Joint State Political Directorate), characterized the industrial trusts' reporting as "fantasy" and "qualified lies."

The retention of power by the Bolsheviks and NEP policy were incompatible any longer, as well as no longer were compatible the further development (more precisely, the construction) of totalitarian statehood and intra-party democracy. Then collectivization (or rather the complete plunder and enslavement of the peasantry), industrialization and great terror followed. During collectivization, the village lost its most energetic and enterprising owners. In 1932-1933, the country was plunged into starvation due to huge grain supplies abroad to pay for foreign engineering products. As a result, about 10 or 15 million people died. A passport system was introduced, which meant the second edition of serfdom (the peasants did not receive passports).

By the end of the 1930s, the USSR had become one of the four industrially developed countries in the world, capable of producing any kind of the most complex industrial products. Thus, the situation on the eve of the First World War was restored by the beginning of the Second World War. However, it was done at the expense of the total impoverishment of the village and the total exploitation of the entire population of the USSR, intimidated by the great terror.

In the conditions of totalitarianism, economic reforms supplemented by political ones yielded great results, but these results were accompanied by a complete lack of rights of the general population. There had never been before such a terrorist, anti-legal policy towards the entire people of the country. And most importantly, despite all the successes in economic, technical and military development, the state built by the communists was not ready for a military clash with another totalitarian monster that 
created a rather powerful coalition on the western borders of the USSR. It seems possible to conclude that already in the early forties the state system showed its insolvency (Krasnov and Shablinsky, 2008).

Another interesting problem is the relationship between economic policy, legal policy and internal party policy under the conditions of totalitarian development. After all, this is precisely where one of the reasons for the victory of the third revolution in Russia in the early nineties of the XX century lies.

Immediately after the death of V.I. Lenin in 1924, a fierce struggle for power broke out in the Bolshevik Party. It was a battle of Stalin, Rykov, Zinoviev against Trotsky first, then Stalin, Rykov and Bukharin against Kamenev, Zinoviev, and Trotsky. During this struggle, any kind of legal opposition in the USSR, and then any dissent in general was put to an end.

In parallel with the struggle within the party, repression was rained down on ordinary citizens. Failures in the industry development were explained by the intrigues of enemies, pests, and spies. Intelligentsia evoked great mistrust, since 1928 a series of court proceedings were launched against it. The Shakhty case, the case of the "Industrial Party", and the case of the "Labor Peasant Party" were fabricated.

In the early thirties, there were still people in the Communist Party who wanted to fight Stalin. The group of I. Smirnov, the hero of the civil war in Siberia, who headed the Siberian Revolutionary Committee, could become the center of their rallying. Zinoviev and Kamenev with their supporters, the Bukharinites, the Union of MarxistLeninists of Martemyan Ryutin tended to favour him. But in late 1932 - early 1933, the OGPU defeated the alliance at the stage of its formation. The last dissatisfied with Stalin were shot after the 17th Party Congress, at which a significant number of votes were cast against the "leader of the peoples".

It should be emphasized that on the eve of the Great Patriotic War the administrativecommand system of economic management had great opportunities for mobilizing the country's economic potential, but only in case of intensive development. It was characterized by flexibility and agility with a rigid repressive production and personnel management system (Arkhipova, 2003).

In 1930s in the USSR, a special social stratum was formed in the group of employees and the intelligentsia - the nomenklatura - the upper layer of the party and Soviet apparatus and mass public organizations. After the Great Patriotic War, the nomenklatura began to turn into an autonomously functioning force, possessing undivided and uncontrolled management of all the state property, which was the main source of power.

The country witnessed a violation of all major legislative acts and established norms of internal party life. There were no Party Congresses from March 1938 to October 
1952. The plenary sessions of the Central Committee turned into meetings of Stalin's close associates and were convoked only at his request. 1947 famine broke out in the USSR due to crop failure, as a result about 1 million people died. At the same time, the first monetary confiscation reform took place - the exchange of money at the rate of 10 rubles. for $1 \mathrm{rub}$. True, after it a decline in prices began and public consumption funds began to increase. In the cities the welfare started growing, but all this was achieved by robbing a village that was mere surviving.

After Stalin's death a struggle for power between Malenkov, Khrushchev and Beria took place, but it was brief. Khrushchev came out the winner. Later the years of his rule were a "thaw" after the fierce Stalinist winter.

Since the agricultural crisis in the USSR became permanent, in 1954 a decision was made to develop the virgin lands. The extensive development possibilities were still not exhausted, and the economic recovery continued. In the late fifties and early sixties, the leadership of the USSR tried to reform the management of industry and construction, that is to shift from the sectoral principle of management to the territorial one through the abolition of sectoral ministries and the creation of local councils of national economy. This reform failed to be effective and it was eventually abandoned.

The debunking Stalin's cult of personality, the mass release of prisoners turned into an upsurge in social activity in 1956-1964. The first, albeit small and unorganized, protests of the population took place: workers and intelligentsia - an example of which was the demonstration of workers in Novocherkassk in 1962.

At the turn of 1950-1960, the tendency of the USSR leaders to solve ever-growing economic problems at the expense of the population was clearly visible. In 1961 another monetary confiscation reform was carried out (10 to 1 again), then production tariff rates were reduced by $1 / 3$, and retail food prices increased by increased by approximately the same amount from May 1962. A wave of new oppression hit the individual household plots of collective farmers.

The trials of the "currency dealers" and Novocherkassk events participants are just some of the examples of violation the legislative norms in the USSR (Vlasov, 2010). This showed that despite the successes in the development of industry, science, technology, education, the country was still gradually slipping into a deep crisis. There was an attempt to avoid it by the coup when in the autumn of 1964 N.S. Khrushchev was removed from all the posts at a plenum of the Central Committee of the CPSU, and Brezhnev-Kosygin-Podgorny-Shelepin group came to power.

Thus, the situation like that in the imperial Russia repeated: economic reforms cannot rectify the situation if they are not accompanied by legal and political transformations. Under conditions of a totalitarian political regime, a mobilization and commandadministrative system, as well as of a powerful repressive network (VChK-NKVD- 
$\mathrm{KGB}$ ), it was possible to keep the situation under control, but this only meant its temporary freezing, that is, the things Russian empire failed to do at the beginning of the XX century due to the lack of the security service development was done in the USSR. But there was still one caveat, the empire was a market economy where competition took place. In the USSR civil life and private property were maximum restricted which led to the lack of competition, but attempts were made to replace it with "socialist competition". As a result, the economy inevitably had to come to deep stagnation (Marchenko, 2015).

\subsection{The Reform of the Economy and Crash of "State Socialism"}

In 1965, an attempt was made in the USSR to reform the economy by introducing self-financing at enterprises. But it was a complete failure since it did not change the foundations of the command and control management system. Moreover, the implementation of the reform was even more conservative than the project itself. Its implementation met with strong resistance from the administrative bodies, which strongly believed it to be an encroachment on their rights and power. In fact, the reform was stymied from the very beginning, the old methods of control and planning were applied.

In 1966 - 1967 the negative aspects of the reform became already evident; the reasons were its initial inconsistency and half-heartedness first of all. So, in the early seventies the reform was completely abandoned. It should be noted, however, that the 1965 economic reform managed to delay the production rates decline.

In general, the sixties became a turning point in the history of the USSR. A powerful industrial and scientific potential was created in the country at the cost of tremendous efforts and sacrifices. Soviet society became not only industrial, but also urban, educated, and new problems raised. By the early eighties' specialists with higher and secondary education accounted for about $33 \%$ of the urban population, with a total of 180 million people. As a result, there was an imbalance of jobs, job vacancies (especially for low-skilled jobs) appeared while there was an excess staff situation for technical and engineering positions. At the same time, the outflow of a large number of people from rural areas created a shortage of workers in the agricultural sector, which worsened its already difficult situation.

The first Brezhnev decade (from the mid-sixties to the mid-seventies) was marked by a slow but progressive rise in the standard of living of the population (it began to decline only in the early eighties). The situation was affected by the positive impulse given to the Soviet economy during the "thaw" and the reform of 1965. In addition, the energy crisis and the rise in oil and gas prices on the world market created additional favorable conditions for this. In the seventies the USSR "earned" about 170 billion petrodollars. 
Despite the growth in the number of educated people, as the country developed the lack of intellectual potential was getting more and more severe. The exact and natural sciences flourished (although there were also failures in genetics and cybernetics), but the humanities, economic and sociological sciences, were in a deep crisis. In the communist movement itself, an attitude was entrenched that hindered the development of Marxism, and ultimately blocked its development. The last major theorist of Marxism was Antonio Gramsci, whose works were ignored in the USSR.

Thanks to the USSR victory in World War II, the "Socialist Commonwealth" arose. However, liberal-minded communist leaders began to come to power in the countries of Central and Southeastern Europe, which were the members of the Council for Mutual Economic Assistance (CMEA). They started economic reforms that did not correspond to Soviet ideas about socialism. In fact, Hungary, Czechoslovakia, Yugoslavia were the USSR's experimental sites, the experience of which had to be carefully studied and analyzed. But there was no one to do this, there was no adequate economic science.

Moreover, the USSR positioned itself as a "big brother" in the socialist community. The party and government leaders of the European socialist countries were supposed to remain within the limits. As soon as Dubchik's government in Czechoslovakia opened the doors too wide for private enterprise, the troops of the USSR, the GDR and Bulgaria were sent to suppress the "counterrevolution" in 1968.

It was 1968 that became the point of no return for the USSR. The opportunity to change, as the Chinese leaders led by Deng Xiaoping did after the death of Mao Zedong, was missed. Moreover, in the conditions of the incipient economic "stagnation", the foreign policy of the USSR became increasingly adventurous in character (the desire for the constant expansion of the socialist system at the expense of the "third world" countries - Vietnam, Laos, Afghanistan, Ethiopia and the provision of "allies" with cheap energy carriers and raw materials). Major joint economic projects were the "Druzhba" oil pipeline and the "Soyuz" gas pipeline, the "Interkosmos" space program, and the construction of industrial enterprises.

By the beginning of the eighties the USSR delivered 508 million tons of oil to the countries of Central and South-Eastern Europe, on credit at highly discounted prices. And this money was often not paid. By the end of the eighties, the amount of nonperforming loans was about $\$ 160$ billion (most of them were not returned later).

However, the main thing was that the development of the USSR economy was still extensive, so the transition to energy-labor-saving production was impossible. The intensive growth of the administrative-bureaucratic apparatus worsened the situation: every year new central ministries and departments including numerous subordinate organizations appeared. If there were 29 union-republican ministries in 1965, then by 
1985 there were 160 of them. About 18 million people worked at different levels of the administrative apparatus - $1 / 7$ of the working population.

Since the beginning of the 1980s, tendencies of a deep, socio-economic, structural crisis of the entire system of "state socialism" started rapid development in the USSR.

In 1985, a new leadership came to power headed by Mikhail Gorbachev, the last General Secretary of the CPSU, the first and last president of the USSR. A course towards liberalization (or, as they said at that time, democratization) of the political and state regimes of the USSR was taken, and it was decided to start with economic reforms. Gorbachev tried to stage his "revolution from above", but he had neither his own strength and determination, nor the required number of personnel, nor time. The resolutions of the Central Committee of the CPSU and the USSR Council of Ministers adopted in 1985-1988, as well as the laws to change economic life, turned out to be far from perfect, and were deformed by the pressure of the apparatus and by-laws.

Only in 1990 there were real shifts in economic reform. New laws made it possible for economic structures to develop. But it was too late. The country was slipping into a revolutionary situation that fully corresponded to Lenin's statement - "the upper classes cannot, and the lower classes do not want to live in the old way." And in the European countries of the socialist community, a wave of "velvet" and not velvet revolutions had already begun.

In 1989-1990 the party apparatus was losing the real power. In January 1990 movements of open political opposition to CPSU began to appear. Since the autumn of 1992 under the conditions of the union state collapse a broad opposition movement "Democratic Russia" was being formed in the RSFSR. Against the background of the "parade of sovereignties" the leadership of the USSR, headed by Gorbachev started a tough power policy to preserve the USSR.

Attempts to preserve the Union by force finally upset the fragile balance of power in Soviet society having discredited both the party's policy and the Union state as a whole. The drama of the great power collapse culminated in the events of August 1991. The attempted coup d'état meant the final collapse of the communist utopia in the country. The third Russian revolution of 1991-1993 began, culminating in a change in the type of the state and the establishment of a qualitatively new form of government.

The situation of 1917 was repeated, but now there were much more suitable conditions for the collapse of the empire, conditions which had been created by the communists themselves.

With the collapse of the Communist Party, the prohibition of its structures, which were the real core of the statehood of the USSR, a time bomb set by the communists detonated. The union, created on a national basis, collapsed. But the totalitarian Soviet 
republic was replaced by a semi-presidential republic, a genuine federal form of government was established, and the partocratic state regime was replaced by a dualistic one (Sergeev, 2016).

In the Russian Federation, radical economic reforms were launched, which led to a drop in living standards in the nineties and a confrontation between the President of the Russian Federation and the Supreme Council, which grew into an open armed conflict in Moscow, which ended with the dismantling of Soviet power bodies throughout the country and the adoption of the Constitution of the Russian Federation of 1993.

\section{Discussion}

Thus, such a long historical review and its analysis clearly confirm the hypothesis about the specifics of the economic and legal development of Russia.

The country's economic reforms were either half-hearted (those of Alexander II and P.A. Stolypin) or did not achieve the goal at all (as in the case of post-war development in the USSR), if they were not supported by serious legal transformations of a political nature. In other words, if the state power did not want to negotiate with civil society and take certain steps towards it, then the country fell into a revolutionary crisis even in the conditions of sustainable economic development (Marchenko 2015).

Economic reforms implemented in time could reduce the severity of social and political confrontation, and even stop the civil war as it happened in 1921 when the NEP was introduced. But one important point is necessary to be stressed. Both in the past and in the present a lot depends on the personality of the leader in Russia and on the strength of the power structures, exactly the security service.

Shifting from the policy of reforms during the reign of Alexander II-Alexander III was provoked by the activity of socialist revolutionaries and failure of the political police and security services to control the situation. Vice versa, the unwinding of the NEP proceeded in the conditions of not just tightening the activities of law enforcement bodies (they completely controlled the situation in the country), but of unleashing terror. Any protests became impossible.

The question of the possibilities and prospects of totalitarian and post-totalitarian development remains open. In its extreme manifestations, totalitarianism does not allow any kind of opposition and dissent. The backbone is the two verticals: the party vertical and the state security one, and the basis is the complete domination of the state form of ownership. Economic development is extensive.

However, a high level of development and a certain increase in well-being are possible, although in the end the formed elite strives to solve state problems at the 
expense of the people. However, totalitarianism can have fewer clear forms, allowing the development of private property relations to a certain extent as in the case of Hungary, Czechoslovakia, and Yugoslavia (Chirkin, 2000).

The transition from totalitarian development to post-totalitarian development is accompanied by large-scale economic and political reforms. Moreover, two options are possible: the revolutionary, observed in Europe, and the reform of histories (China and Vietnam), the difference between which lies in the elimination or preservation of the dictatorship of the Communist Party.

\section{Conclusion}

Summing up this study, we can say that the European way of development has received a certain refraction in Russia. Initially, the Russian Empire was formed on such a poverty of economic emptiness that one wonders how this could happen at all. In fact, it was only in the second half of the 19th century that full-fledged economic and political reforms took place in Russia, and the leadership of the empire was constantly under increasing pressure from both reactionary and revolutionary extremist forces. As a result, the political and legal component of Russian reforms was severely reduced and, despite the successes in economic and technological development, Russia was plunged into revolutionary upheavals.

The Russian revolutions of the first quarter of the 20th century had damaging consequences for the country's population. Civil society was virtually destroyed. Legal reforms were either declarative in nature or clearly repressive.

The NEP era stands apart in the history of Soviet Russia. The New Economic Policy put an end to the civil war and demonstrated once again the fact that if the economic reform is not complemented by a legal, liberal one, and especially when the totalitarian regime remains, then its results are ephemeral.

Another point is the role of the police and security services in the context of reform. In fact, the lack of resources on the part of security services. led to the death of two great reformers of Russia: Alexander II and Stolypin, which was one of the reasons for backtracking. And it leads us to another important circumstance - the role of the leader in the history of Russia and in the reform process. The death of the Russian Empire and the collapse of the USSR were largely due to the weakness of their leaders.

A separate issue is the issue of civil society and political police. The Communists managed to minimize the civil society. The political police won a complete victory. However, this turned into a stagnation in development. The suppression of the humanities, in fact the elimination of economic sciences, led to the inability to analyze the processes taking place in the world socialist system and to chart the course to overcome the crisis. 
Regarding the political police, we can say that its fight against the opposition, dissident movement, dissent makes economic reforms practically impossible. The failure of the 1965 reform and the end of the "thaw" practically coincide. Attempts to slow down the revival of civil society in the second half of the eighties made economic reform impossible, and ultimately led to the collapse of the Soviet state (although, of course, one should not forget about its doom, because all the socialist federations built on the national principle collapsed). And yet, 70 years of single-party existence have developed a very stable social apathy towards party life. In fact, there are no real democratic political parties in Russia, and the activities of the security service have nothing to do with it.

\section{References:}

Arkhipova, T.G. 2003. Statehood of Modern Russia. Moscow, RGGU.

Avrutin, Yu.E. 2003. Police and Militia in the Mechanism of Ensuring State Power in

Russia: Theory, History, Perspectives. St. Petesburg, Legal Press Centre.

Chirkin, V.E. 2000. The Modern State. Moscow, International Affairs publ.

Ivashko, M.I. 2016. History (XIX century). Moscow, RGUP publ.

Kerimov, A.D. 2014. The Modern State: Theoretical Questions. Moscow, NORMA.

Krasnov, M.A., Shablinsky, I.G. 2008. The Russian System of Government: A Triangle with One Corner. Moscow, Institute of Law and Public policy.

Marchenko, M.N. 2015. The Rule of Law and Civil Society (Theoretical and Legal Research). Moscow, Prospekt.

Sergeev, A.A. 2016. Russian Statehood in the XXI Century: Main Problems. Moscow, Prospekt.

Syrykh, V.M. 2014. A History of the State and Law of Russia, in 2 vol. Moscow, NORMAINFRA.

Tikhomirov, Yu.A. 2013. The State. Moscow, NORM-INFRA.

Vlasov, V.I. 2010. The Leader of the Executive Power Structures in Russia. Moscow, Vuzovskaya kniga publ.

Vlasova, G.B. 2009. Legitimation of the Public Authority Institutions in Political, Legal and Sociocultural Terms (On the Example of the Evolution of Justice). Rostov-on-Don, SFEDU publ. 